\title{
Simone de Beauvoir on the Situation and Rights of French Women Colonizer
}

\author{
Nathalie Nya \\ Pennsylvania State University
}

\begin{abstract}
The goal of this paper is to establish from Simone de Beauvoir's perspective what happens when the situation and rights of French women are examined from the purview of their position as colonial subjects—as women colonizer. Following the analysis of Beauvoir as featured in The Ethics of Ambiguity and The Second Sex, the author first begins by examining the situation and rights of French women colonizer as it relates to the situation of the colonized. And then, the author examines the situation and rights of these women from their own stands as women and in relationships to the situation and rights of white French men. The paper concludes that while French women may have experienced white privilege, they suffered from gender oppression deriving from their second-class status as French colonial subjects.
\end{abstract}

Keywords: gender, colonialism, women colonizer, colonized, voting rights, oppression, freedom

\section{Introduction}

In this paper, I present from Simone de Beauvoir's perspective on the situation and rights of French women. I do this by showing the analysis of Beauvoir as featured in The Ethics of Ambiguity and The Second Sex. First, I present the situation and rights of French women colonizer as it relates to the situation of the colonized and then analyze the situation and rights of these women as they relate to the situation and rights of White French men. In the end, I argue that even though French women may have experienced white Privilege, they suffered from gender oppression deriving from their second-class status as French colonial subjects.

\section{The Colonized and Women Colonizer}

In The Second Sex and The Ethics of Ambiguity, Beauvoir made references to the colonial situation of France, ${ }^{1}$ in order to show the place of French colonialism within her analysis of oppression and gender oppression in particular that she presented in these texts. However, the analysis of Beauvoir showed that her notes on the gender oppressive colonial situation of France were made to enable her to elaborate more on the situation of white women. In other words, Beauvoir used the condition of the colonized in order to further reflect on the condition of white women. ${ }^{2}$ She did so especially in The Second Sex, in her attempt to use the condition of the colonized in order to shed light on the situation of white women within France and the French empire. To Beauvoir, while the oppressive development of the colonist and in particular the male colonial administrator could cease to exist with the end of the colonial system, the gender oppression imposed upon

Nathalie Nya, Ph.D, lecturer of Philosophy, Department of Philosophy, Pennsylvania State University, USA; main research fields: 20th Century French Philosophy with a Focus on Feminism, Ethics, Social and Political Philosophy, and Critical Theory of Race.Email: nun116@psu.edu. 
women. ${ }^{3}$ Relating the colonial system more to a system of political oppression than to a specific system of racial oppression, as Sartre did, Beauvoir claimed that gender oppression was more permanent than colonial oppression, within the French empire. Beauvoir prioritized gender oppression over colonial oppression, and demonstrated precisely how gender oppression overarched colonial oppression.

To illustrate her point on the relation between gender oppression and colonial oppression, Beauvoir drew on the situation of blacks as it related to the situation of white women. Writing during the period of French colonial rule, Beauvoir alluded to the ways French colonialists created the caricature of the black man as thievish, lazy, and deceitful in order to racially discriminate against black men. ${ }^{4}$ According to Beauvoir, the caricature that French colonialists created for white women resulted in a more fundamental oppression, in the sense that, unlike black men who did not take the racial stereotypes of French colonialists as a reflection of their identity, white women did take on the gender stereotypes of the French colonialists as a reflection of their femininity. ${ }^{5}$ The difference between the situation of black men and white women's response to the stereotypes of French colonialist shows the permanent effects of gender oppression and the permanent effects of the traditional order of patriarchy upon the situation of women in the Western world. To Beauvoir, black men, even if they had to accept these stereotypes, as in the case of black slaves, ${ }^{6}$ knew that they were being stereotyped, while women, on the other hand, generally did not realize that they were being stereotyped. White women simply respectfully obeyed the social dictates of their stereotypical representations, an observation that led Beauvoir to argue that the situation of white women was thus even worse than the situation of black slaves and colonial natives. ${ }^{7}$ White women rarely ever questioned the sexist ideologies white men associated with their feminine identities. To Beauvoir, these women took the sexist ideologies behind the gender stereotypes enforced by white men only as a positive reflection of Western female gender tradition and of their femininity.

It should be noted that already in her description of the colonial context of France, Beauvoir associated racial oppression with the condition of black men and gender oppression with the condition of white women. French colonialists, also referenced as French administrators, ${ }^{8}$ in view of the historical fact that French men dominated and ruled the French colonial administration, were intended by Beauvoir to designate French men. By explicitly identifying the French colonialists as French men, Beauvoir primarily examined the position of French women in terms of their position as oppressed, rather than as oppressors. A limit then in Beauvoir's analysis on French women written during colonial France, in the 1940s, was that she did not consider French women as oppressor subjects. By primarily examining the position of French women as oppressed, Beauvoir failed to consider, for example, the ways in which French women colonizers contributed to the stereotypes made about black men, in addition to ignoring black women.

Beauvoir's attempt to relate racial oppression with black men and gender oppression with white women, is an issue that I critique about The Second Sex specifically. This categorization limits what Beauvoir's writings on gender oppression from the 1940s that can offer to the racial and gender oppression of black women. Beauvoir's race/gender analogy creates problems for an analytical context that would explicitly take into account the situation of colonized women. Simply stated, as Kathryn Gines explains in her article, "Sartre, Beauvoir, and the Race/Gender Analogy," the race/gender analogy is the use of racial oppression as an analogy for gender oppression. ${ }^{9}$ One shortcoming of the analogy is that it tends to emphasize the situation of black men and white women while ignoring or negating the situation of women of color. ${ }^{10}$ Furthermore, as it is visible in The Second Sex, the race/gender analogy often codes race as black man and gender as white woman, neglecting the situation of women of color. ${ }^{11}$ Accordingly, another shortcoming of the analogy is that it is frequently 
exploited to support members of groups and their causes even when those groups often participate in or are complicit with some form of anti-black racism. ${ }^{12}$ Beauvoir's analysis is not racist towards blacks. But her analysis on the racial situations of black men vis-à-vis the gender oppression of "white" women fails to acknowledge that black women are confronted by both a woman question and a race problem. ${ }^{13}$ Thus, the intersectionality of the race/gender dyad as experienced within the situation of black women is lost within Beauvoir's analysis on the interconnection between race and gender oppression.

Although Beauvoir's analysis on gender oppression from the 1940s alludes to the situation of non-European women in classical antiquity, for example, as her analysis of Jewish and Arab women shows, ${ }^{14}$ there are no references within her analysis of gender oppression that explicitly claims to identify the situation of non-European women within the colonial context of France. What we see more in The Second Sex is Beauvoir's attempt to examine the situation of French women, such as herself, within the patriarchal history of France and the history of western norms and knowledge.

\section{The Situation and Rights of Women Colonizer}

On the gender oppression situation of white women/women colonizers in France, since I find it important to discuss the situation of women colonizer within the French empire (and since Beauvoir briefly discussed the context of colonialism in The Ethics of Ambiguity) in this section, I will supplement my analysis of women colonizer as featured in The Second Sex with Beauvoir's analysis of colonialism in The Ethics of Ambiguity. As she observed in The Second Sex, the French revolution did not change the situation of women in France. ${ }^{15}$ After the revolution, women were still oppressed and subordinate to men in France. Precisely because of their subordinate position in the aftermath of the revolution, the universal suffrage that the male population acquired through the establishment of the Declaration of Rights of Man was not extended to French women. The “enlightened elites”"16 or "middle-class men"17 as Beauvoir stated in The Ethics of Ambiguity, were opposed "to the extension of universal suffrage by adducing the incompetence of the masses, of [French] women, of the natives [men and women] in the colonies” (Beauvoir, 139). ${ }^{18}$ Aligning the condition of French women to that of the condition of French colonized subjects and claiming neither French women nor the colonized were educated or fit to vote, allowed French middle-class men to deny the right to vote to these members of French empire, Beauvoir said. Thus, they made women and colonized men and women politically less free. Though I will discuss Beauvoir's analysis on voting rights among the colonized and white women in further detail later, I want to note that I take up this issue in this section of the chapter because it is with liberal political rights that Beauvoir in part discussed the social and political oppression of colonized and white women. So with her analysis of liberal political rights, Beauvoir sought to show how the colonized and white women were disenfranchised. As Beauvoir explained in The Ethics of Ambiguity, "all oppressive regimes become stronger through the degradation of the oppressed" (Beauvoir, 101). ${ }^{19}$ As it was the case for Arabs in Algeria, for example, women in France, claiming that neither French women nor the colonized were worthy of the vote denigrated the oppressed to a position in reality that was comparable to imagined perception that the French administrators had of these members of the French empire.

Moreover, to Beauvoir, the claim on the part of middle-class men that neither French women nor the colonized could vote was based on the assumption that these members of the French empire were ineligible to rule. $^{20}$ Yet as she argued, making French women and the colonized eligible to vote did not necessarily predestine these members of the French empire to govern and participate in making the laws of France. 
Granting the right to vote to French women and the colonized, unlike French men, would not have been a decision to let them govern. ${ }^{21}$ Instead, the eventual decision granting the right to vote to French women and the colonized only further reflected the limitations and inconsistencies that these members of the French empire experienced within their acquired social, economic, and political rights.

Specifically, in the chapter titled, “The Independent Woman,” from The Second Sex, Beauvoir examined the overlooked social, economic, and political constraints that French women faced in the aftermath of acquiring the right to vote in 1944. As Gail Weis notes, Beauvoir's analysis was made to show the multiple aspects from which women experienced oppression. ${ }^{22}$ I would add that her analysis also sheds light on the ways women understand their subjectivity.

Even with the right to vote, Beauvoir argued that women were still in a condition of vassalage. ${ }^{23}$ The political status of women was that of subordination to the political status of men. As she attempted to show in the chapter, the fact that women were granted the right to vote did not necessarily affect the infrastructure of French society. ${ }^{24}$ The right for women to vote did not make the rights of women symmetrical to the rights and privileges of men. In claiming to enfranchise women through humanist law, man attempted to describe and justify women's oppression with a description of himself, and his theories and histories of humanity. ${ }^{25}$ Granting the right to vote to women in virtue of humanist principles, as the studies of Sara Heinämaa suggest, further silenced a cohesive examination of the oppression of women, ${ }^{26}$ due to the reality that women's relationships to the history of politics have been different from that of men. ${ }^{27}$ Historically, women have been politically disadvantaged in comparison with men. As the work of Carole Pateman has shown in The Sexual Contract, liberal political theories did not view women as the subject of political discourse, which meant that women were excluded from the original political contract. ${ }^{28}$ In view of the history of women and politics, granting the right to vote to women perpetuates myths, as Judith Okely states, about "women's objective subordination and oppression" (22). ${ }^{29}$

To show an aspect of women's oppression unaddressed by the universal suffrage, Beauvoir centered her analysis on the persistence of economic disenfranchisement among the majority of women in France. Writing The Second Sex during the middle to late of 1940s, Beauvoir observed that while it was the case that each women citizen has the right to vote, "these civil liberties remain theoretical as long as they are unaccompanied by economic freedom” (679). ${ }^{30}$ The economic disenfranchisement of women in France negated the paltry effort on the part of French men to grant these women the right to vote, such that if women were not financially independent, the liberal political rights that they were acquiring would not render their situation symmetrical to the situation of men. In economic terms, women, unlike men, were politically and socially restricted.

Here Beauvoir suggested that it was wage labor and financial independence that can put the liberty of women in practice. ${ }^{31}$ The woman, she describes, "when she is productive, active, ....in her projects she concretely affirms her status as subject; in connection with the aims she pursues, with the money and the rights she takes possession of, she makes trial of and senses her responsibility” (680). ${ }^{32}$ In describing what women ought to strive for (education, money, freedom, and responsibility), Beauvoir alluded to the legacy of women's unpaid labor primarily practiced in households, which made women responsible for the care and wellbeing of others, and financially dependent on their husbands.

Through housework, the sense of responsibility that women had for others and the dependence on their husbands, prevented them from being both independent and responsible for themselves. The title to property rights under political liberalism, as shown in the works of John Locke, suggested that what a man worked for 
ought to belong to him. ${ }^{33}$ Yet, precisely because housewives were women and not men, the work that these women did within the household could not guarantee them a sense of self-sovereignty. Housework denied these women a title to private property. Through housework, women, on average, owned nothing, and because of this, they were denied a sense of self-autonomy and personal responsibility.

The analysis that I present here is supported by the scholarship of Toril Moi on the works of Beauvoir. Toril Moi argues that the chapter on the independent woman suggests, "as long as women are prevented from earning their own living, they will always be dependent on others" (74).$^{34}$ Being an independent woman depends upon the material condition of earning a living. More specifically, it is the paid work that women do in the public sphere and rather not in the household (private sphere) that can attempt to give women a title to a liberal political identity. A title to a liberal political identity, as Carole Pateman explains, is made upon a person's place within the sphere of civil society. ${ }^{35}$ From the perspective of liberal political theories founded primarily through the works of Hobbes, Locke, and Rousseau, civil society is divided into the public sphere and the private sphere. But as Pateman shows, the division of civil society into the public sphere and the private sphere reflects the order of sexual political difference between the rights of men and the rights of women. ${ }^{36}$ Establishing the function of the public/private divide within liberal political theories, Pateman asserts that "the private sphere is typically presupposed as a necessary, natural foundation for civil, i.e., public life, but treated as irrelevant to the concerns of political theories and political activities.” Given that the private sphere is part of civil society but separated from the public or civil sphere, it follows a person that could only gain a liberal political identity through the exercise of activities in the public sphere.

Furthermore, given the sexual political order of liberal political theories, both men and women had rights to the private sphere and a life in the household, but only men had rights to a life in the public sphere. Traditionally then, men were the only ones who had rights to civil liberty and their liberties were considered to be the relevant concerns that would establish civil society. By being historically barred from the public sphere, women did not gain a title to a liberal political identity, nor did they influence the establishment of liberal political rights through their lives within households. Politically, the lives of women within the households could never give women a sense of self-sovereignty. So when Beauvoir urged women to become economically independent, she was actually urging women to take part in the civil sphere, in the hope that their participation in the economy would alter not only the subject position of women, but also the infrastructure of France.

However, Beauvoir became pessimistic and settled on the reality that the infrastructure of the French liberal political system could not be easily changed. From this point of view, Beauvoir complicated her position on the economic enfranchisement of women to assert that, "it is not to be supposed, however, that the mere combination of the right to vote and a job constitutes a complete emancipation: Working, today, is not liberty" (681). ${ }^{37}$ Given the deeply entrenched subordinate status of women in French society, the infrastructure of the French liberal political system, earning a wage along with having the right to vote did not necessarily free women. As Nancy J. Hirschmann shows, if women enter the workforce from the social liberal perspective that they are inferior to men, the market will ensure their failure. ${ }^{38}$ It is the assumption that society has lots of women that will affect the performance of women in the workforce and the wages paid to women in the workforce.

Toril Moi presents a stronger interpretation of Beauvoir's chapter that allows Moi to argue that independent women are not free. ${ }^{39}$ To Toril Moi, independent women are not free precisely because, "women actually seeking paid work, however, are confronted with class exploitation and sexist oppression at every turn” 
(74). ${ }^{40}$ The classism and sexism built into the infrastructure of the French liberal political system perpetuate the subordination of independent women and overlook inconsistencies within the liberty of these women.

As Beauvoir explained, once women joined the workforce, they took on the majority of male working class workers, who were exploited under capitalism. ${ }^{41}$ Furthermore, as she continued to explain, "the social structure has not been much modified by the changes in women's condition; this world always belonged to men, still retains the form they have given it” (680). ${ }^{42}$ Because the French system is built upon the ideals, the theories, and histories of men, the fact that women were granted the right to vote and earn wages does not necessarily affect the social and political structure of French society. The limited appearance of women's rights does not change classism, nor does it change sexism.

The classism and sexism that independent women routinely encounter reflect the irresolvable conflict, as Sonia Kruks shows that these women face when seeking "human freedom" from the purview of their feminine destiny. ${ }^{43}$ To Beauvoir, the feminine destiny of women, "which is to construct an identity that reaffirms their dependence on others because of their sex, or which is to construct an infantilized identity" (37), ${ }^{44}$ posed peculiar problems for an independent human individual. ${ }^{45}$ The advantages she said, "man’s enjoys, which makes itself felt from his childhood, is that his vocation as a human being in no way runs counter to his destiny as a male” (682). ${ }^{46}$ When a man becomes independent, he engages himself in the project of man, of which he is destined to be. When a woman becomes independent, she has to reject her destiny. A man is unlike a woman because in becoming independent, he is not divided. ${ }^{47}$ In becoming independent, women have to renounce part, if not all, of their femininity. But Beauvoir stated in essentialist terms, "to renounce her femininity is to renounce a part of her humanity" (682). ${ }^{48}$ Given the state of history and politics, women could not take part in human freedom without following their feminine destiny. Yet, given that the feminine destiny of women implied a historicized and politicized state of subordination, "women's oppression cannot be overcome except within the framework of the fuller abolition of human oppression” (64). ${ }^{49}$ So, for example, in order to consider the economic disenfranchisement of women in France, women's lack of economic freedom in France, and the economic oppression of working class, men should also be examined.

Following the interpretation supported by the studies of Kruks might prevent us from assuming that to have the right to human freedom and to be independent does necessarily imply that women ought to follow the destiny of men. For the purpose of my study, to be independent does necessarily imply that one ought to follow the destiny of white men. While the right to vote and earning a living might enable women to maneuver within the capitalist French liberal political system, it is only when the descriptions, theories, and histories of women are justly included within the development of the infrastructure of France that the legacy of women's subordination can potentially alter the power structure between French men and French women. Thus, examining both the political and the economic predominance of French men over French women can only provide us with some justification for the liberation of French women. To Beauvoir in particular, the gender and sexual predominance of French men over French women should also be contested.

\section{Conclusion}

To Beauvoir, women colonizers were oppressed. The meager political rights they acquired during French colonial rule, such as the right to vote, further revealed the problems and contradiction within their gender situation, which was built upon patriarchy - thus built on the social and political status of being subordinate to French men. As this paper argues, while French women may have experienced white privilege, they suffered 
from gender oppression deriving from their second-class status as French colonial subjects.

\section{Notes}

1. Simone de Beauvoir, The Second Sex (New York: Vintage Books, ed., 1989), 598 \& 723; Simone de Beauvoir, The Ethics of Ambiguity (Secaucus N.J.: The Citadel Press, 1972), 101.

2. Beauvoir, The Second Sex, 598.

3. Ibid., 723.

4. Ibid., 616.

5. Ibid..

6. Ibid., 598.

7. Ibid..

8. Ibid., 723.

9. Kathryn T. Gines, “Sartre, Beauvoir, and the Race/Gender Analogy,” in Convergences: Black Feminism and Continental Philosophy, ed., Maria del Guadalupe Davidson, Kathryn T. Gines, and Donna-Dale L. Marcano (New York: SUNY Press, 2010), 36.

10. Ibid..

11. Ibid..

12. Ibid..

13. Ibid., 44

14. Beauvoir, The Second Sex, 84-85.

15. Ibid., 109.

16. Beauvoir, The Ethics of Ambiguity, 138.

17. Beauvoir, The Second Sex, 109.

18. Beauvoir, The Ethics of Ambiguity, 139.

19. Ibid., 101.

20. Ibid., 139.

21. Ibid..

22. Gail Weiss, "Challenging Choices: An Ethic of Oppression," ed., Margaret Simons, The Philosophy of Simone de Beauvoir: Critical Essays (Bloomington: Indiana University Press, 2006), 243.

23. Beauvoir, The Second Sex, 679.

24. Ibid., 680.

25. Sara Heirnämaa, “Simone de Beauvoir’s Phenomenology of Sexual Difference,” ed., Margeret Simons, The Philosophy of Simone de Beauvoir: Critical Essays, 32.

26. Ibid..

27. Máire Fedelma Cross, “Women and Politics,” ed., Abigail Gregory, Women in Contemporary France (New York: Berg, 2000), 89.

28. Carole Pateman, The Sexual Contract (Stanford Calif.: Stanford University Press, 1988), 5.

29. Judith Okely, "Rereading the Second Sex,” ed., Elizabeth Fallaize, Simone de Beauvoir: A Critical Reader (London, New York: Routledge, 1998), 22.

30. Beauvoir, The Second Sex, 679.

31. Ibid..

32. Ibid., 680.

33. John Locke, Second Treatise of Government, 1st ed., (Indianapolis, Ind.: Hackett Pub. Co., 1980), 19.

34. Toril Moi, “Independent Women” and “Narratives of Liberation,” ed., Elizabeth Fallaize, Simone de Beauvoir: A Critical Reader, 74.

35. Pateman, The Sexual Contract, 11.

36. Ibid..

37. Beauvoir, The Second Sex, 681

38. N. J Hirschmann, Gender, Class, and Freedom in Modern Political Theory (Princeton Univ Pr, 2008), 215.

39. Fallaize, Simone de Beauvoir: A Critical Reader, 75.

40. Ibid., 74.

41. Beauvoir, The Second Sex, 680.

42. Ibid.

43. Sonia Kruks, “Beauvoir: The Weight of Situation,” ed., Elizabeth Fallaize, Simone de Beauvoir: A Critical Reader, 74.

44. Beauvoir, The Ethics of Ambiguity, 37.

45. Beauvoir, The Second Sex, 682.

46. Ibid.. 
47. Ibid..

48. Ibid..

49. Fallaize, Simone de Beauvoir: A Critical Reader, 64.

\section{Works Cited}

Beauvoir, Simone. The Ethics of Ambiguity. Secaucus N.J.: The Citadel Press, 1972.

---. The Second Sex. Vintage Books ed.. New York: Vintage Books, 1989.

Fallaize, Elizabeth. Simone de Beauvoir: A Critical Reader. London, New York: Routledge, 1998.

Gines, Kathryn T.. "Sartre, Beauvoir, and the Race/Gender Analogy.” Convergences: Black Feminism and Continental Philosophy, ed., Maria del Guadalupe Davidson, Kathryn T. Gines, and Donna-Dale L. Marcano. New York: SUNY Press, 2010. 35-52.

Gregory, Abigail. Women in Contemporary France. New York: Berg, 2000.

Hirschmann, N. J. Gender, Class, and Freedom in Modern Political Theory. Princeton, NJ: Princeton Univ Pr, 2008.

Locke, John. Second Treatise of Government. 1st ed.. Indianapolis Ind.: Hackett Pub. Co., 1980.

Pateman, Carole. The Sexual Contract. Stanford Calif.: Stanford University Press, 1988.

Simons, Margaret. The Philosophy of Simone de Beauvoir: Critical Essays. Bloomington: Indiana University Press, 2006. 